\title{
A pilot feasibility study on SARS-CoV-2 detection method based on nasopharyngeal lavage fluid
}

Running title: SARS-CoV-2 detection by nasal lavage

Daniele Frezza ${ }^{1}$ Cristoforo Fabbris ${ }^{1}$, Leonardo Franz ${ }^{1,2}$, Elisa Vian ${ }^{3}$, Roberto Rigoli ${ }^{3}$, Rosalba De Siati ${ }^{1,2}$, Enzo Emanuelli ${ }^{1}$, Bertinato Luigi ${ }^{4}$, Paolo Boscolo-Rizzo ${ }^{2,5}$, Giacomo Spinato ${ }^{1,2,6}$

${ }^{1}$ Unit of Otorhinolaryngology, AULSS 2 - Marca Trevigiana, Treviso, Italy

${ }^{2}$ Department of Neurosciences, Section of Otolaryngology, University of Padova, Treviso, Italy

${ }^{3}$ Department of Clinical Pathology, AULSS 2 - Marca Trevigiana, Treviso, Italy

${ }^{4}$ National Institute of Health, Head of the Scientific Secretariat, Rome, Italy

${ }^{5}$ Department of Medical, Surgical and Health Sciences, Section of Otolaryngology, University of Trieste, Trieste, Italy

${ }^{6}$ Department of Surgery, Oncology and Gastroenterology, Section of Oncology and Immunology, University of Padova,

Padova, Italy

The present work was performed at Treviso Hospital, Treviso, Italy.

\section{Corresponding author's contact information:}

Paolo Boscolo-Rizzo, MD, Department of Medical, Surgical and Health Sciences, Section of Otolaryngology, University of Trieste, Trieste, Italy; email: paolo.boscolorizzo@units.it

Keywords: saline solution; COVID-19; diagnosis; preventive care; nasal irrigation; swab

Funding: This study was not supported by any funding.

Conflict of Interest: All authors declare that they have no conflict of interest.

Financial disclosures: The authors have nothing to disclose.

Ethical approval: All procedures performed in this study involving human participants were in accordance with the ethical standards of the institutional and/or national research committee and with the 1964 Helsinki declaration and its later amendments or comparable ethical standards. The present study was approved by the ethics committee of Treviso and Belluno provinces. Written informed consent was obtained by all participants enrolled in the study. 
medRxiv preprint doi: https://doi.org/10.1101/2021.06.14.21258619; this version posted June 14, 2021. The copyright holder for this preprint (which was not certified by peer review) is the author/funder, who has granted medRxiv a license to display the preprint in perpetuity. All rights reserved. No reuse allowed without permission.

\section{Authors' contribution}

Concept and design: Frezza, Fabbris, Boscolo-Rizzo, Spinato

Acquisition, analysis, or interpretation of data: Frezza, Fabbris, Franz, Vian, Rigoli, Menegaldo, De Siati, Boscolo-Rizzo, Spinato

Drafting of the manuscript: Frezza, Fabbris, Franz, Boscolo-Rizzo, Spinato

Critical revision of the manuscript and supervision: Frezza, Fabbris, Emanuelli, Bertinato, Boscolo-Rizzo, Spinato

Acknowledgements: The authors would like to acknowledge Jerry Polesel for his support in statistical analysis of the data. 
medRxiv preprint doi: https://doi.org/10.1101/2021.06.14.21258619; this version posted June 14, 2021. The copyright holder for this preprint

(which was not certified by peer review) is the author/funder, who has granted medRxiv a license to display the preprint in perpetuity.

All rights reserved. No reuse allowed without permission.

\section{Abstract}

Objective - Nose and nasopharyngeal swab is the preferred and worldwide accepted method to detect the Severe Acute Respiratory Syndrome Coronavirus 2 (SARS-CoV-2) within the nose and nasopharynx. This method may be linked with possible difficulties, such as patient's discomfort or complications. This paper shows a pilot study of SARSCoV-2 detection with nasal and nasopharyngeal lavage fluids.

Methods - Nasal lavage fluid was collected from patients who were submitted to SARS-CoV-2 screening test, due to a preceding positive rapid antigen test. A control group was enrolled among healthcare professionals whose nasopharyngeal swab tested negative. Nasal lavages were performed using isotonic saline solution injected through a nasal fossa. Both lavage fluid and traditional nasopharyngeal swab were analyzed by real-time PCR and antigenic test. Results - A total of 49 positive subjects were enrolled in the study. Results of the analysis on lavages and nasopharyngeal swabs were concordant for 48 cases, regardless of the antigenic and molecular test performed. RTPCR resulted weakly positive at swab in one case and negative at lavage fluid. Among the control group (44 subjects) nasopharyngeal swab and lavage fluid analyses returned a negative result. Sensitivity of the molecular test based on nasal lavage fluid, compared to traditional nasal swab, was $97.7 \%$, specificity was $100 \%$, and accuracy was $98.9 \%$, with high agreement (Cohen's k, 0.978).

Conclusion - Nasal and nasopharyngeal lavages resulted to be highly reliable and well tolerated. A larger series is needed in order to confirm these results. This approach may potentially represent a valid alternative to the traditional swab method in selected cases. 
medRxiv preprint doi: https://doi.org/10.1101/2021.06.14.21258619; this version posted June 14, 2021. The copyright holder for this preprint

(which was not certified by peer review) is the author/funder, who has granted medRxiv a license to display the preprint in perpetuity.

All rights reserved. No reuse allowed without permission.

\section{Introduction}

The current pandemic related to severe acute respiratory syndrome coronavirus 2 (SARS-CoV-2) infection, which causes COVID-19 (COronaVIrus Disease 2019), requiring massive population testing, rises some issues regarding diagnostic accuracy and feasibility on large scale of the current sample collection techniques.

As it has been demonstrated, samples from nasopharynx have the highest chances to contain material suitable for SARS-CoV-2 detection [1]. Accordingly, nasopharyngeal swab is currently the first choice for SARS-CoV-2 infection diagnosis [2]. However, it requires a steep learning curve for healthcare providers and is operator dependent. The diagnostic accuracy of nasopharyngeal swabs depends indeed on their success in reaching the nasopharynx. Such procedure may be affected by both poor performing technique (also due to anatomical misconception) and morphological barriers in the route to nasopharynx, including septal deviation, leading to increased discomfort during procedure [3]. Patient's compliance to nasopharyngeal swabs is critical, especially in planning massive populationbased testing campaigns. Nasopharyngeal swab is not completely devoid of adverse events risk, like epistaxis, septal hematoma or abscess, retention of foreign bodies from broken swabs or even cerebrospinal fluid leak [4,5]. Possible

mistakes among health-care professionals deriving from long-lasting sessions of swab procedures must be also considered, with relative consequences on reliability of results [6].

Therefore, alternatives to the traditional swab should be developed to collect nasopharyngeal samples. Collection of lavage fluid has long been employed as a technique to obtain biological samples from the lower respiratory tract.

The aim of this study was to preliminarily explore the feasibility and accuracy of nasal lavage as a method to collect samples from the nasopharynx for SARS-CoV-2 detection.

\section{Methods}

The present study was approved by the ethics committee of Treviso and Belluno provinces (ethic vote: $871 /$ CESC). Written informed consent was obtained by all participants enrolled in the study. We collected nasal lavage fluid from patients who were submitted to SARS-CoV-2 screening test who were positive on the first rapid antigen test performed on a nasopharyngeal swab and returned to the Treviso SARS-CoV-2 Screening Center to perform the confirmatory PCR-based test. A control group was enrolled among healthcare professionals whose nasopharyngeal swab tested negative. 
medRxiv preprint doi: https://doi.org/10.1101/2021.06.14.21258619; this version posted June 14, 2021. The copyright holder for this preprint

(which was not certified by peer review) is the author/funder, who has granted medRxiv a license to display the preprint in perpetuity.

All rights reserved. No reuse allowed without permission.

Each patient underwent the standard nasopharyngeal swab for molecular analysis. Subsequently nasal lavages were performed using isotonic saline solution injected through a nasal fossa with device Lavonase Lab. The solution mixed with nasal and nasopharyngeal secretions, once evacuated from the other nostril, was collected directly in a sterile tube (details are shown in Figure 1). After nasopharyngeal swab and nasal lavage collection, each participant was asked to report their perception of procedure discomfort by a $100 \mathrm{~mm}$ Visual Analogic Scales (VAS), ranging from 0 (no discomfort) to 100 (maximal discomfort).

Both lavage fluid and traditional nasopharyngeal swab were analyzed by real-time PCR (Allplex SARS-CoV-2 Assay, Seegene) and antigenic test (SARS-CoV-2 Rapid Antigen Test, Roche, F. Hoffmann-La Roche Ltd) for SARS-CoV-2. For real-time -PCR analysis the considered detection limit to indicate negative samples was Ct? $=$ ? 40 .

Results of the traditional swab and the nasal lavage fluid analyses were compared calculating sensibility, specificity and accuracy and corresponding confidence intervals $(\mathrm{Cl})$. Agreement was evaluated through Cohen's kappa. Difference in VAS discomfort between traditional swab and nasal lavage was evaluated through Mann-Whitney test.

\section{Results}

All results are reported in Supplementary Table 1 . The case group was composed of 49 consecutive subjects (mean [range] age, 49.0 [18-80] years; 30 [61.2\%] male). In all subjects except one, the results of the analysis on lavage fluid and traditional nasopharyngeal swab were concordant, regardless of the antigenic and molecular test performed. Only in case $\mathrm{n}^{\circ} 20$ RT-PCR resulted weakly positive at swab (cycle threshold of E gene 37, cycle threshold of RdRP 38 and N genes 36 ) and negative at lavage fluid. A total of 44 subjects were enrolled in the control group (mean [range] age, 45.0 [26-61] years; 28 [63.6\%] female). In all these cases, both the nasopharyngeal swab and the lavage fluid analyses returned a negative result. Therefore, the sensitivity of the molecular test based on nasal lavage fluid was $97.7 \%$ (95\% $\mathrm{Cl}: 88.2 \%-99.6 \%)$ while the specificity was $100 \%(95 \% \mathrm{Cl}: 92.7 \%-100 \%)$ resulting in an accuracy of $98.9 \%(95 \% \mathrm{Cl}: 94.2-$ $99.8 \%$ ) compared to the molecular test based in traditional nasal swab; high agreement was found (Cohen's k, 0.978) (Table 1).

Overall, nasal lavage fluid collection was atraumatic and well tolerated with no adverse events. Collection of the lavage was performed twice in two patients because they did not sufficiently bend their head. Patients reported much 
medRxiv preprint doi: https://doi.org/10.1101/2021.06.14.21258619; this version posted June 14, 2021. The copyright holder for this preprint (which was not certified by peer review) is the author/funder, who has granted medRxiv a license to display the preprint in perpetuity.

All rights reserved. No reuse allowed without permission.

lower discomfort with nasal lavage (median VAS: 0; interquartile range: 0-16) than with nasopharyngeal swab (median VAS: 68 ; interquartile range: $31-85 ; p<0.0001)$. 
medRxiv preprint doi: https://doi.org/10.1101/2021.06.14.21258619; this version posted June 14, 2021. The copyright holder for this preprint

(which was not certified by peer review) is the author/funder, who has granted medRxiv a license to display the preprint in perpetuity.

All rights reserved. No reuse allowed without permission.

\section{Discussion}

The diagnosis of SARS-CoV-2 infection based on RT-PCR from nasopharyngeal nasal lavage was observed to be both feasible and accurate with specificity and sensitivity being $97.7 \%$ and $100 \%$, respectively, when compared with the gold standard PCR from nasopharyngeal swab.

The use of nasal lavage overcomes the critical issues risen by traditional nasopharyngeal swabs. First of all, such approach is easier to perform and more standardized, reducing the training time for the operators, or it can be performed by the patient himself with a reduction in the risk of contagion of COVID-19 for the operators and reduction of health costs. Moreover, issues related to collection, transport and storage could be greatly reduced [7].

Lavages might also allow to collect sufficient nasopharyngeal material even from anticoagulated patients or from those with severe septal deviation or with reduced compliance, like pediatric or non-cooperative subjects. Moreover, such approach avoids direct contact of a swab with nasal and nasopharyngeal mucosa. This is not only a compliance issue: nasal mucosa brushing, beside producing discomfort, damages the muco-ciliary clearance system, which may take several weeks to be repaired [8], leaving patients with less effective physical barriers against infectious agents.

The results in this clinical study preliminarily suggest an excellent tolerability and a minimal risk of operatordependence. In selected cases, collection of nasal lavage fluids may be a potentially advantageous method to obtain samples from nasopharynx for SARS-CoV-2 detection and prevent COVID-19 spreading, compared to the traditional swab. However, this procedure should be more extensively investigated in larger cohort studies to evaluate the testretest reliability, calculate limit of detection, and further assess patients' compliance and safety from side effects.

\section{Conclusion}

According to the present pilot clinical study, nasal and nasopharyngeal lavages resulted to be highly reliable and well tolerated, even if the research was conducted among a small case series. Further studies among a larger number of positive and negative subjects is needed in order to confirm these results. If these aspects will be confirmed, diagnosis based on nasal and nasopharyngeal lavage fluid may potentially represent a valid alternative to the traditional swab method. 
medRxiv preprint doi: https://doi.org/10.1101/2021.06.14.21258619; this version posted June 14, 2021. The copyright holder for this preprint (which was not certified by peer review) is the author/funder, who has granted medRxiv a license to display the preprint in perpetuity. All rights reserved. No reuse allowed without permission.

\section{References}

1. Tong $\mathrm{Y}, \mathrm{Bao} A$, Chen $\mathrm{H}$, et al. Necessity for detection of SARS-CoV-2 RNA in multiple types of specimens for the discharge of the patients with COVID-19. J Transl Med. 2020;18(1):411. Published 2020 Nov 2. doi:10.1186/s12967-020-02580-w

2. Spinato G, Gaudioso P, Boscolo Rizzo P, et al. Risk management during COVID-19: safety procedures for otolaryngologists. Acta Biomed. 2021;92(1):e2021105. Published 2021 Feb 16. doi:10.23750/abm.v92i1.11281

3. Higgins TS, Wu AW, Ting JY. SARS-CoV-2 Nasopharyngeal Swab Testing-False-Negative Results From a Pervasive Anatomical Misconception [published online ahead of print, 2020 Sep 17]. JAMA Otolaryngol Head Neck Surg. 2020;10.1001/jamaoto.2020.2946. doi:10.1001/jamaoto.2020.2946

4. Fabbris C, Cestaro W, Menegaldo A, et al. Is oro/nasopharyngeal swab for SARS-CoV-2 detection a safe procedure? Complications observed among a case series of 4876 consecutive swabs. Am J Otolaryngol. 2021;42(1):102758. doi:10.1016/j.amjoto.2020.102758

5. Sullivan CB, Schwalje AT, Jensen M, et al. Cerebrospinal Fluid Leak After Nasal Swab Testing for Coronavirus Disease 2019 [published correction appears in JAMA Otolaryngol Head Neck Surg. 2020 Dec 1;146(12):1181]. JAMA Otolaryngol Head Neck Surg. 2020;146(12):1179-1181. doi:10.1001/jamaoto.2020.3579

6. Scattoni ML, Fulceri F, D'Ancona FP, et al. Interim guidance for the appropriate support of the health workers in the SARS-CoV-2 emergency scenario. Version May 28, 2020. ISS Working Group Mental health and emergency COVID-19 2020, 14 p. Rapporto ISS COVID-19 n. 22/2020 Rev. - English version

7. Minghetti L, Bertinato L, Cara A, et al. Recommendations for collection, transport and storage of COVID-19 biological samples. Version of April 15, 2020. ISS COVID-19 Translational Research Working Group 2020,19 p. Rapporti ISS COVID-19 n. 13/2020 - English version

8. Cassano M, Russo GM, Granieri C, Cassano P. Cytofunctional changes in nasal ciliated cells in patients treated with hyaluronate after nasal surgery. Am J Rhinol Allergy. 2016;30(2):83-88. doi:10.2500/ajra.2016.30.4284 
medRxiv preprint doi: https://doi.org/10.1101/2021.06.14.21258619; this version posted June 14, 2021. The copyright holder for this preprint (which was not certified by peer review) is the author/funder, who has granted medRxiv a license to display the preprint in perpetuity.

All rights reserved. No reuse allowed without permission.

Table 1. Distribution of SARS-COV-2 positive and negative cases among nasal swabs and lavages.

Positive swabs Negative swabs Row total

\begin{tabular}{cccc}
\hline Positive lavages & 43 & 0 & 43 \\
\hline Negative lavages & 1 & 49 & 50 \\
\hline Column total & 44 & 49 &
\end{tabular}


medRxiv preprint doi: https://doi.org/10.1101/2021.06.14.21258619; this version posted June 14, 2021. The copyright holder for this preprint

(which was not certified by peer review) is the author/funder, who has granted medRxiv a license to display the preprint in perpetuity.

All rights reserved. No reuse allowed without permission.

\section{Figure legend}

Figure 1. Scheme of the used nasal lavage. The head is bent down. The isotonic saline solution enters through a nasal fossa (upwards arrow), passes through the nasopharynx (curved arrow) and exits the other nasal fossa mixed with nasal and nasopharyngeal secretion, to be collected in the lab tube (downwards arrow) through a collection funnel.

Figure 2. Example of the use of the device. A syringe is filled with isotonic sterile fluid $(10 \mathrm{cc})$ and located on the right part of the device. The top of the syringe is linked with a cone-shaped rubber dispenser. The collection tube is inserted at the bottom in the left part. The patient bends down his head onto the device and introduces the top of the dispenser in his right nostril for a few millimeters. Then, he presses the plunger so that the fluid passes into the right nasal fossa, the nasopharynx, and the left nasal fossa. At the end, the fluid exits the left nasal fossa and collects into the test tube.

\section{Supplementary Table legend}

Supplementary Table 1. Series of patients who underwent nasal and nasopharyngeal lavage and nasopharyngeal swab a nalysis for SARS-CoV-2 detection. For RT-PCR analysis the considered detection limit to indicate negative samples was Ct回>回40. 


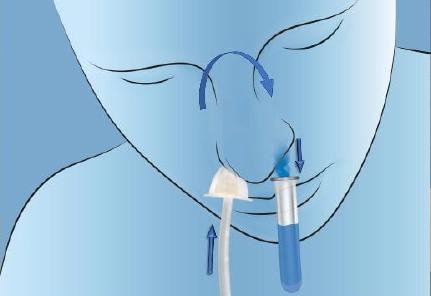




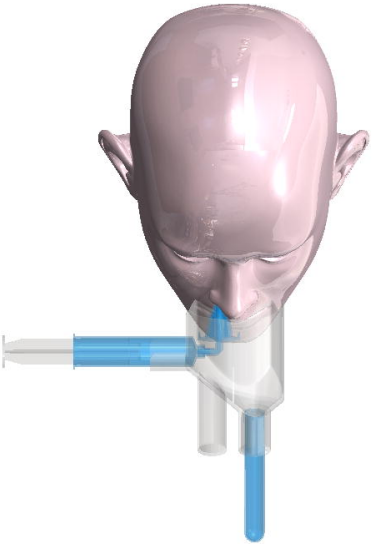

